Удк [37-057.36]:811.11:[159.91:(684.3)]

DOI: https://doi.org/10.35387/od.2(16).2019.100-107

Loputko Olena - Candidate of Pedagogical Sciences, Associate Professor, Associate Professor of the Foreign Languages Department of the National Academy of Internal Affairs

ORCID ID: https://orcid.org/0000-0002-5331-9635

E-mail: loputko1979@gmail.com

\title{
MIND MAP TECHNOLOGIES IN TEACHING CADETS ENGLISH FOR SPECIFIC PURPOSES
}

\begin{abstract}
The article is devoted to the implementation of the mental mapping method into the process of English for the specific purposes study by the cadets of the higher educational establishments of the Ministry of Internal Affairs of Ukraine.

The analysis of the method's usage as in the educational process so that in the following professional education is introduced. It is underlined, that the implementation of such kind of a technology will benefit not only the formation of a specific discipline's knowledge but also the creation of complex cognitive skills on the interdisciplinary level with the possibility of their usage in the process of the professional duties' performing. It is stated that the method gained the world wide acknowledgement and is in the process of constant perfection.

At the process of the method's implementation the necessity to include the peculiarities of the cadets' daily routine is stressed. The terms of study, educational process's intensiveness, reglamented daily routine and service duties are encounted.

The main Tony Buzan's author recommendations are worked out. On this ground the levels of the method's implementation are introduced. The main successive stages of the work: initial, semi-productive and creative were proposed. Their qualitative amount depends on the subject's knowledge, the skills of the work according to this technology and the level of the teacher's inclusiveness.

Theoretical and practical background of the papers ground the effectiveness of the mind mapping technology's implementation into the educational process of the higher educational establishments of the Ministry of Internal Affairs of Ukraine.
\end{abstract}

Key words: mental map, English for specific purposes, interdisciplinary, productive, creative, mental literacy.

Лопутько Олена Анатоліївна - кандидат педагогічних наук, доцент, доцент кафредри іноземних мов Національної академії внутрішніх справ

ORCID ID: https://orcid.org/0000-0002-5331-9635

E-mail: loputko1979@gmail.com 


\section{ТЕХНОЛОГІЯ ВИКОРИСТАННЯ МЕНТАЛЬНИХ КАРТ У НАВЧАННІ КУРСАНТІВ АНГЛІЙСЬКОЇ МОВИ ПРОФЕСІЙНОГО СПРЯМУВАННЯ}

Анотація. Стаття присвячена застосуванню методу побудови ментальних карт в прочесі вивчення іноземної мови професійного спрямування курсантами вищих навчальних закладів Міністерства внутрішніх справ України.

Представлено аналіз використання методу побудови ментальних карт як під час організації навчання, так $і$ в процесі подальшої профресійної освіти. Підкреслено, що впровадження роботи за такою технологію сприятиме не тільки засвоєнню іноземної мови профресійного спрямування, але й формуванню навичок комплексної пізнавальної роботи курсантів на міждисциплінарному рівні з можливістю застосування набутих вмінь та навичок в процесі здійснення профресійних обов'язків.

Під час формування тих принципів та умов, які є підгрунтям організації навчальних занять наголошено на необхідності врахування організації життєдіяльності курсантів. Так, було враховано терміни проходження навчання, інтенсивність навчального процесу, регламентований режим дня та необхідність виконання службових обов'язків.

Розглянуто основні авторські принципи засновника метода Тоні Бузана та на їх основі запропоновано основні етапи впровадження методу в навчальний процес. Запропоновано послідовні три рівні складності у роботі над методом: початковий, частково продуктивний та творчий. Їх якісне наповнення варіюється залежно від рівня володіння навчальним матеріалом, сформованості навичок роботи за такою технологією та ступенем залучення викладача до організаційних процесів.

Теоретична та практичні складові даної роботи свідчать про доцільність впровадження методу побудови ментальних карт в навчальний процес вищих навчальних закладів системи МBC.

Ключові слова: ментальна карта, технологія, англійська за профресійним спрямуванням, міждисциплінарний, продуктивний, креативний, ментальна грамотність

Articulation of the problem. Contemporary level of the society and its institutions' development creates the necessity in changing the paradigm of the specialists' formation in the sphere of higher education. The importance of the English for specific purposes study, proved by the latest researches, is reflected in the documents of the Ministry of Education and Science of Ukraine and is supported by the papers of the Ministry of Internal Affairs of Ukraine and internal acts of the National Academy of Internal Affairs and other educational 
establishments of this field (Concept of development ..., 2019; Concept of the educational reform ..., 2016). The peculiarities of the cadets' process of study strongly underlines the increasing actuality of making a research in the sphere of choosing such methods and technologies of teaching them the foreign languages which will benefit the final result - their possessing such skills and abilities which make possible professional communication on all the necessary levels. Besides, it's important to stress on the necessity of developing cognitive skills which give them abilities to further learning. One of the possible ways of achieving this complex task is teaching of the mind mapping techniques during the English language study.

Analysis of recent publications. The problem of using intellect-card technology in the process of learning a foreign language is devoted to the study of domestic (L. Gurev, V. Karpov, N. Kozmin, I. Korotyaev, I. Lukyanchenko, etc.) and foreign scholars (S. Bukhari, J. Dostal, G. King, A. Leyden, etc.). Scientists, in particular, have elucidated the peculiarities of formation of grammatical competence of students of language specialties by means of using intellectual cards; the specificity of the use of intellect cards in the teaching of different types of speech activity, in the formation of reproductive skills and skills of students in higher education is characterized.

Grounded on the abovementioned, the main purpose of this paper may be defined as: the usage of the mental mapping technologies while teaching cadets English for specific purposes. According to the following purpose, the next aims can be cleared out: to study the background and origin of the term "a mental map" and its modification; to follow the spread of the technology among the world; to introduce the usage of the mind mapping technology in specific spheres, especially in the sphere of the law enforcement education; to work out the gradual introduction of the mind mapping technology into the educational process of the higher educational establishments of the Ministry of Internal Affairs of Ukraine; to outline the effectiveness and to define the further perspectives of the mind mapping usage in the educational and professional activity of a law enforcement officer.

The study will be presented on the ground of historical, content and structural analysis, their modifications and variations, elements of observation and modelling will also be included into the work.

Research findings. At the beginning of the study it is worth to define the term "a mind map». Although, the backgrounds of the concept can be followed through centuries, the beginner and popularizer of the mental mapping technologies is considered to be Tony Buzan, an American psychologist, who introduced this method to the mass practical usage. He defines a mind map as a powerful gra phic technique, which activates both hemispheres of the brain and supports all its functions and, therefore, increases the cognition process greatly (T. Buzan, B. Buzan, 1994). The method gained popularity and the following researches: G.P. Adesope, G.H. Cunningham, B. Holland, J. Davis, J. Gowin, J. Nesbit, J. Novak, P. Farrand and a lot of others. Implementation of this technology into a lot of spheres led to the wide range of modifications 
throughout the world (a mental map, a content map, a logical map/diagram, a spidergram), but nevertheless contemporary academic definitions can be cleared out. Cambridge dictionary states that «a mind map is a type of diagram (= a simple plan) with lines and circles for organizing information so that it is easier to use or remember (Cambridge dictionary, 2020)». Oxford Dictionary presents this term as «a diagram that presents information with a central idea in the middle and connected ideas arranged around it (Oxford Dictionary, 2020) ».

During the last decade the usage of this technique becomes specific and incorporates into nearly all the spheres of the human life. Researches all over the world implement it into different spheres. There can be mentioned digitalization, natural sciences, learning process at colleges and schools. The geography of the method's implementation especially emphasizes its international character and necessity of its implementation into educational process in Ukraine. As to the field of law enforcement, the usage of the mind mapping techniques can also be found in the net. Some of the latest examples can be: T. Buzan's personal presentation of the mind mapping technique to the Dubai Police (Blog of the ..., 2014), Indian police usage of mind maps while performing police reforms (Insight IAS, 2018), Hong Kong police content in drawing mental maps with the aim of sharing personal experience with the colleagues (Winners of mind mapping ..., 2019).

Grounded on all the above mentioned the author has a reasonable background to consider the mind mapping technology to be necessary for implementation into educational process at the National Academy of Internal Affairs. Before giving some practical recommendation of organization the learning process according to the principles of mapping some peculiarities of the cadets' learning process must be taken into account. The most important for us among them are: the short period of the theoretical auditory education with the following possibility to continue education at the correspondence department, the need to increase the practical usage of the formed skills and abilities at the time of probation and during performing service duties, the peculiarities of combining theoretical study with daily routine which includes special police duties, the need to form a language background which is strong enough to be satisfactory to continue higher education after a sufficient period of the theoretical learning absence (practice, vacation, probation). From this point of view, features of the mental mapping which create strong associations and activate the processes of recalling and refreshing language skills and abilities can be considered one of the most suitable methods of the groups' work organization. The other specific condition is the qualitative component. Language and cognitive skills and abilities of the members of the cadets' groups are quite different. That is why the organization of the study according to such a complex model must include gradual introduction of its elements. The content features of the technology give such possibilities while been introduced accounting to different amount of fields, components, the complexity of establishing logical relations, the level of creativity, teachers' guidance, possibilities to work individually or as a member of the project group. 
While giving some practical advice $\mathrm{T}$. Buzan recommends to include the following rules of $s$ mind map's creation (Blog of the Purdue University, 2020):

1. Start in the centre with an image of the topic, using at least 3 colours.

2. Use images, symbols, codes and dimensions throughout your mind map.

3. Select key words and print using upper or lower case letters.

4. Each word/image must be alone and sitting on its own line.

5. The lines must be connected, starting from the central image.

6. The central lines are thicker, organic and flowing, becoming thinner as they radiate out from the centre.

7. Make the lines the same length as the word/image.

8. Use colours - your own code - throughout the mind map.

9. Develop your own personal style of mind map.

10. Use emphasis and show associations in your mind map.

11. Keep the mind map clear by using radial hierarchy, numerical order or outlines to embrace your branches.

It also must be cleared, that the process of formation of mind mapping skills must be gradual and correspondent to the language knowledge and cognitive skills of the cadets. So, the whole process of the technology's implementation must be divided into three periods: initial, semi-productive and creative.

Initial period is introduced with the beginning of the educational discipline English for specific purposes' study. It is characterized by revision of lexical and grammar material, which the following introduction of the specific law enforcement content. During this period mind maps can be presented in order to revise and systematize grammar, to present collocations, to introduce vocabulary, to scheme the text, to form the ground of oral discussion and so on. The teacher's explanations, and control are the characteristic features of the time. In other words, he/she explains the mechanisms of usage and introduces preferences of the mapping. The main task of the period is the usage of the prepared schemes and patterns on the specific contextual material and awareness of further independent or collective usage of the method.

This period is to be short and include 5-10 practical lessons due to the peculiarities of the cadets' cognitive abilities.

The following semi-productive period is introduced by the guided creative work of the cadets. At this stage the cadets are to demonstrate their creative abilities according to the given topic. Here only the sketch is to be presented by the teacher. More complex character of the content and relations between them are to be introduced.

There are a lot of possible examples of the work with mental maps on the second stage. The technology may be shown while working with vocabulary and semantic groups, grammar times and examples of their practical usage (widely spread in the foreign sources), textual information. The choice of marks, lines, icons depend on the teachers and cadets personally and may vary 
according to the topics, main tasks of the lessons and personal peculiarities of the participants of the educational process. After the second period cadets are to be able to analyze the text and give the mental map of it under the direct supervision of the teacher.

The 3-rd period is to be introduced by the productive level of the cadets' work. Here the high level of motivation is to be supported by the sufficient knowledge of the subject and the highly developed cognitive skills. It must be stated that not all the cadets and study groups will satisfy the whole amount of demands, introduced on it. At the beginning of this stage the sketches of logical relations (Table1), may be introduced.

Table 1

Possible logical links

\begin{tabular}{|c|c|c|}
\hline is a word for & pertains to & causes \\
\hline is a kind of & participle & derivation \\
\hline is an instance of & attribute & theme \\
\hline is a member of & opposes & space \\
\hline is a part of & verb group & time \\
\hline is a substance of & entails & aim \\
\hline is similar to & also see & usage \\
\hline
\end{tabular}

According to the given demands the cadets are to organize the contextual material depending on the theme of the lesson. The meta task on this level is to prepare them to the independent creative work with every kind of material. The examples on this level may be introduced while individual and group creative work with further introduction in the group, analysis, feedback and correction of the results. The sketch of the recommended by the Purdue University mental map here is complex and may be introduced be such an items' organization (Blog of the Purdue University, 2020) (Picture 1).

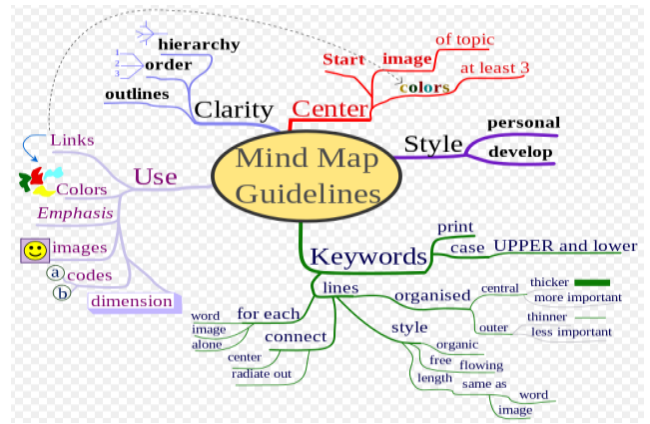

Picture 1. Sketch of the Map

On this level positive results may be achieved not only in the language 
sphere, but also give the benefit to the interdisciplinary learning due to the possibility of their cross usage. Another great opportunity is to use online programs in order to create mind maps. As the restricted abilities of the article's format gives no opportunity to demonstrate all the peculiarities of the mental mapping possibilities, the example created by one of the cadets on the topic «Evidence» in online program Coggle can be introduced under the address: https://coggle.it/gallery.

At the conclusion of the article it must be stated, that the work which is held whilst researching of this question includes the analysis of the papers of foreign and native authors with the aims of the term "a mental map" definition, work on the development of its modification and content, the possibilities and results of its implementation into the educational process of the higher law enforcement educational establishments, the benefits of its usage during languages' study organization. It may be stated, that implementation of the mind mapping technique into the process of study of the foreign languages will increase not only the languages' skills and abilities, but also will be beneficial to the cognitive skills and abilities, necessary for performing future professional duties, formation. The restricted volume of the article gives no opportunity to research all the features and possibilities of the technology. The most competitive fields of the further researches are seen in the spheres of the careful planning of the work with this method and in the work with online maps' constructors, the results storage and sharing.

\section{Bibliography}

Концепція розвитку англійської мови в університетах (2019). Поточна редакція від 13.08.2019. URL: https://mon.gov.ua/ua/news/monstvorilo-koncepciyu-rozvitku-anglijskoyi-v-universitetah-u-dodatkuriven-v1-obovyazkova-umova-vstupu-v2-vipusku-vikladannya-profilnihdisciplin-inozemnoyu-ta-movni-skriningi

Концепція рефрормування освіти в міністерстві внутрішніх справ України (2016). Поточна редакція від 25.11.2016. URL: https://ips.ligazakon.net/document/view/MVS675?an=1

Blog of the Dubai Police. Professor Buzan presents his mind mapping at Dubai police (2014). URL: https://m.facebook.com/dubaipolicehq.en/posts/668168699927335

Blog of the Purdue University. Learning technologies. Mind maps. (2020). URL: https://www.pnw.edu/learning-technologies/mind-maps/

Buzan T., Buzan B. (1994) The mind map book. Dutton, New York, 1994. 322. Cambridge Dictionary. (2019).

URL: https://dictionary.cambridge.org/ru/словарь/английский/mind-map

Insight IAS (2018). URL: https://www.insightsonindia.com/wp-

conford
Oxford
Dictionary
(2019).
URL:

https://www.oxfordlearnersdictionaries.com/definition/english/mindmap 
Winners of mind mapping contest awarded (2019). URL: https://www.police.gov.hk/offbeat/1127/eng/7543.html

\section{References (translated and transliterated)}

Concept of development of the English language in universities, as amended on 13.08.2019. URL: https://mon.gov.ua/ua/news/mon-stvorilo-koncepciyurozvitku-anglijskoyi-v-universitetah-u-dodatku-riven-v1-obovyazkovaumova-vstupu-v2-vipusku-vikladannya-profilnih-disciplin-inozemnoyu-tamovni-skriningi (in Ukrainian)

Concept of the educational reform in the Ministry of Internal Affairs of Ukraine, as amended on 25.11.2016. URL: https://ips.ligazakon.net/document/view/MVS675?an=1(in Ukrainian)

Blog of the Dubai Police. Professor Buzan presents his mind mapping at Dubai police (2014). URL: https://m.facebook.com/dubaipolicehq.en/posts/668168699927335 (in English)

Blog of the Purdue University. Learning technologies. Mind maps. (2020). URL: https://www.pnw.edu/learning-technologies/mind-maps/ (in English)

Buzan T., Buzan B. (1994) The mind map book. Dutton, New York, 1994. 322 p. (in English)

Cambridge

Dictionary.

(2020).

URL: https://dictionary.cambridge.org/ru/словарь/английский/mind-map English)

Insight IAS (2018). URL: https://www.insightsonindia.com/wpcontent/uploads/2018/07/Police-Reforms.pdf (in English)

Oxford Dictionary (2020). URL: https://www.oxfordlearnersdictionaries.com/definition/english/mind-map (in English)

Winners of mind mapping contest awarded (2019). URL: https://www.police.gov.hk/offbeat/1127/eng/7543.html (in English)

\section{УДК 378:7.012}

DOI: https://doi.org/10.35387/od.2(16).2019.107-116

Полтавець Наталія Вікторівна - аспірантка Київської державної академії декоративно-прикладного мистецтва і дизайну імені Михайла Бойчука

ORCID ID: https://orcid.org/0000-0001-7124-2999

E-mail: natalka.arts@gmail.com

\section{СУЧАСНИЙ СТАН РОЗВИНЕНОСТІ ТВОРЧОГО ПОТЕНЦІАЛУ МАЙБУТНІХ ХУДОЖНИТКІВ ДЕКОРАТИВНО- ПРИКЛАДНОГО МИСТЕЦТВА}

Анотація. У публікації висвітлено сучасний стан розвиненості творчого потенціалу майбутніх художників декоративно-прикладного мистецтва в процесі вивчення фрахових дисциплін у закладах вищої 